\title{
Isaac Orobio de Castro as a Writer: The Importance of Literary Style in the "Divine Warnings against the Vain Idolatry of the Gentiles"
}

Daniel Levi de Barrios (1635-1701), the scorned and celebrated poet laureate of Amsterdam's Sephardic community, had a complex, ambivalent relation toward his fellow Andalusian countryman Isaac Orobio de Castro. On the one hand, he greatly admired the latter's rapid rise in the Jewish community as well as his reputation as a doctor and champion of Judaism. Barrios welcomed Orobio upon his arrival, so to speak, and no doubt found comfort in the micro-society formed by fellow Andalusians remembering their sunny and fertile homeland in the streets of Amsterdam. ${ }^{1}$ Orobio and Barrios seemed to share many experiences: both were Marranos in Andalusia who renounced the prestige enjoyed in society in order to embrace Judaism and defend it in their literary work. However, Orobio's prodigious career soon revealed an enormous contrast with Barrios' misfortune. Barrios was an exile who lived in poverty and failed to attract the audience from fellow Jews that he believed he deserved, as the prophet Daniel. Yet Barrios' poetical compositions never ceased enjoying popularity, as nobody could write skillful eulogies with the ease of the bard from Montilla. And thus, Isaac Orobio de Castro's works are also adorned with poetic praise by Daniel Levi de Barrios. ${ }^{2}$

In the reception of Orobio's works, Barrios is one of the few (if not the only) among his contemporaries to highlight their literary merits. Orobio de Castro is undisputedly the most popular and widely read of the Sephardic apologists. His works, all circulating in manuscript form, survive in more than sixty copies, a number approached only by Rabbi Saul Levi Mortera's writings. In comparison to Mor-

Harm den Boer, University of Basel

1 Orobio arrived towards the end of 1662 in Amsterdam; Barrios had joined the Amsterdam Jewish congregation some months earlier, as he married Abigail de Pina there on 30 August of that year. See Kaplan, From Christianity to Judaism: The Story of Isaac Orobio de Castro (Oxford: Oxford University Press, 1989), 106, 233.

2 These praises are all included in Isaac Orobio de Castro, Prevenciones divinas contra la vana idolatría de las gentes, vol. 1, edited by Myriam Silvera (Florence: Leo S. Olschki, 2013), 3-10. Barrios furthermore includes Orobio in his Relación de los poetas y escritores de la nación judaica (c. 1682): "Ishac Orobio, médico eminente / con sus libros da envidia a lo sapiente, / Y en lo que escrive contra el atheísta / Espinosa, más clara haze la vista," Harm den Boer, La literatura sefardí de Amsterdam (Alcalá de Henares: Universidad, 1996), 296, 361. The relation between Orobio and Barrios is commented in detail by Kaplan, From Christianity to Judaism, 222-234.

Ә OpenAccess. (c) 2018 Harm den Boer, published by De Gruyter. (c) BY-NC-ND This work is licensed under the

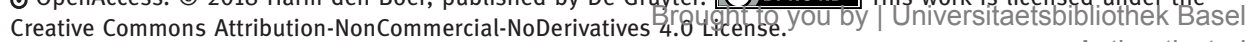
https://doi.org/10.1515/9783110576191-005 
tera, however, Orobio was far better known in the Christian world, both as a personality and through the translation of his polemics, which acquired an active afterlife among the philosophes. I will not comment any further on this aspect which has enjoyed abundant scholarly attention in recent years. ${ }^{3}$ However, what seems important to me is that Orobio enjoys much of his reputation based upon his personality and, above all, the force of his arguments, both due to their dialectical strength and their unparalleled sharpness towards Christianity. ${ }^{4}$ The recent publication of the critical edition of Orobio's Divine Warnings against the Vain Idolatry of the Gentiles (Prevenciones divinas contra la vana idolatría de las gentes) by Myriam Silvera provides the reader with an excellent opportunity to follow the doctor's dialectics in detail, accompanied by opportune and necessary scholarly comments. Having this Spanish text available in a convenient edition also offers the chance to study the Divine Warnings as a literary composition, a task that is sorely needed, as I will argue.

In order to grasp the significance of Jewish apologetics in the Early Modern world, we have become increasingly aware of the importance of two fundamental innovations produced in the genre by Iberian conversos: the use of vernacular language and literary form. Carsten Wilke has admirably described the contribution of Iberian Jews of converso origin to the genre, otherwise known as "Jewish polemics" or "controversy." Wilke shows that the choice of Spanish or Portuguese in such texts reflects a shift in their audience. The new apologetics were oriented towards a lay or unspecialised reader who is-at least rhetorically- in the position to freely choose or affirm his Jewish religion on basis of arguments rather than tradition. Through the choice made for the vernacular or mother tongue of the former conversos, the adoption of literary form or literary genre acquired a whole new dimension in Jewish apologetics. A vast array of possibilities was now open to serve the cause of Judaism, reaffirming the religion against the past experience and the enduring pressure of Christianity: humanist dialogue, scholastic treatise, catechism, humorous or lyric poetry, drama, etc. Each choice was full of intertextual plays and implications

3 Kaplan, From Christianity to Judaism, 451-457; Richard H. Popkin, "The Role of Jewish Anti-Christian Arguments in the Rise of Skepticism," in New Perspectives on Renaissance Thought: Essays in the History of Science, Education and Philosophy in Memory of Charles B. Schmidt, edited by J.H. and S. Hutton (London: Duckworth, 1990) : 159-180; Miguel Benítez, La face cachée des Lumières: Recherches sur les manuscrits philosophiques clandestins de l'âge classique (Paris: Universitas, 1996); Adam Sutcliffe, "Judaism in the Anti-Religious Thought of the Clandestine French Early Enlightenment," Journal of the History of Ideas 64.1 (2003), 97-117; Sutcliffe, Judaism and Enlightenment (Cambridge: Cambridge University Press, 2003); Gianni Paganini, “Orobio e i suoi lettori dall'ebraismo all'illuminismo," in Orobio, Prevenciones divinas, $\mathrm{V}-\mathrm{XV}$.

4 Kaplan, From Christianity to Judaism, 245: "It would be difficult in the remaining writings of Isaac Orobio to find such outspoken language levelled at Jesus and his disciples as is to be found, in plentiful measure, in the present treatise." 
that often challenged the Iberian models their authors had chosen to adopt. ${ }^{5}$ Whereas the printed literature of Iberian conversos and New Jews has increasingly been reappraised for its defiant recontextualisation of hegemonic Iberian social and religious concepts-correcting the idea that the Iberian literature produced in Sephardic exile was an interesting cultural phenomenon that was, in a literary sense, essentially derivative in nature ${ }^{6}$-the vast field of Jewish polemics in Spanish and Portuguese extant in manuscripts has been barely cultivated. ${ }^{7}$

The literary form chosen by Orobio in his Divine Warnings is the tratado or treatise, a global designation for works in prose that could be comprised of literary fiction as well as works of a scientific or didactical nature. ${ }^{8}$ Orobio followed this tradition, which he probably inherited from his academic career, of composing a "writing or discourse that comprehends or explains the species belonging to some particular matter." 9 The rather undefined nature of the genre, oscillating between oral discourse and written exposition and, rhetorically, between the "deliberative" and "judicial” causes, is also reflected in Orobio's text, where reasoning alters with praise or condemnation, and non-personal assertions alter with enunciations in the first person plural, contraposed to the third person plural (e.g. "we"-the Jews-versus "they" - the Gentiles or Christians). The factors that have motivated the present exploration of Orobio's Divine Warnings, are a) the length of the text, b) its semantic and stylistic complexity and, by implication, c) the question of which reader the author had in mind.

The length, above all the verbosity, is a distinctive feature of the Divine Warnings, which becomes all the more evident in its recent critical edition where each of its chapters is accompanied by a summary (in Italian) of its contents. This practice par-

5 Carsten L. Wilke, The Marrakesh Dialogues: A Gospel Critique and Jewish Apology from the Spanish Renaissance (Leiden: Brill, 2014), see the Introduction, 4-8 and particularly Chapter 5, "Invention of a literary genre," 113-150.

6 Works such as those by Abraham Pereyra or Miguel (Daniel Levi) de Barrios were taken as examples of an essentially mimetic discourse, that is introducing or 'copying' the literature of the Iberian siglo de oro in a Jewish context. However such a discourse is not always, in form and content, a "mimesis of antagonism," but often adopts a provoking, polemic dimension. Thus, the 'hegemonic' discourse of Iberian literature is consciously evoked to counter it, in a political or religious sense. Isaac Cardoso's Excelencias de los hebreos (1679) not only imitates the Iberian genre of excelencias literature, but offers its readers the challenging perspective of putting the despised people of Israel above Iberian Gothic supremacy (see Yosef Hayim Yerushalmi, From Spanish Court to Italian Ghetto: Isaac Cardoso: A Study in Seventeenth-Century Marranism and Jewish Apologetics (New York: Columbia University Press, 1971), 357-358, 381-386.

7 A telling example of the 'counter-discourse' to be found in Sephardic polemical literature is provided by the poetry and prose texts of Abraham Gómez Silveyra (1656-1741); see Kenneth Brown and Harm den Boer, El Barroco sefardí: La poesía de Abraham Gómez Silveira, estudio y edición (Kassel: Reichenberger, 2000).

8 Orobio refers to his Divine Warnings as a tratado (Prevenciones divinas, edited by M. Silvera, 190)

9 "Se llama también el escrito o discurso que comprehende o explica las especies tocantes a alguna materia particular. Lat. Tractatus,” Diccionario de Autoridades (1739). 
allels the eighteenth- and nineteenth-century reception of the text, transmitted in considerably shortened versions. ${ }^{10}$ A good example is the French Israël vengé, published in 1770 on the basis of several of Orobio's texts: the two chapters that were extracted from the second part of the Divine Warnings for separate circulation are about half the length of the original. Several scholars have examined the significant changes Orobio's work has undergone in its translation as well as the use of his abridged work by French philosophers; it is not necessary for me to examine this transfer again. ${ }^{11}$ (Neither is it my intention to study the elimination of offending content or terms in other versions, such as in the English translation by Grace Aguilar). ${ }^{12}$ In my opinion, these translations as well as the recent example of Silvera's Italian summaries show that the Divine Warnings' original text was considered too verbose, and perhaps also too intricate for new intended readers of Orobio's work.

If, as I will argue further on, the Divine Warnings displays a general principle of amplificatio which implies repetitions, redundancies and parallel constructions, the text is also governed by complex semantics and style. Many such complexities, to be explored further on, have also been eliminated from the Divine Warnings' translations.

The difficulty of the original text of the Divine Warnings, particularly in its first part, raises an important question: if Orobio's text was perceived as too large or too complex to be passed on in its entirety in translation, what does that mean for the reader the author had in mind? There seems to be a consensus that Orobio wrote his magnum opus for his fellow Sephardim, the former conversos. Even if we do not challenge this opinion, ${ }^{13}$ we should at least be aware of the difference in tone and style as compared to Orobio's other writings. An interesting comparison can be made with the Explanation of the Fifty-Third Chapter of Isaiah (Explicación del capitulo 53 de Isaías), as I will argue further on. In the prologue of the latter, Orobio writes that "these discourses were written on behalf of some persons who live outside of Judaism"; that "this is not written for the learned, therefore its insufficiency is excused." The author had prepared a text for fellow conversos that was ready to

10 See Kaplan, From Christianity to Judaism, 451-464: "Translation of Orobio’s Works in the Eighteenth and Nineteenth Centuries."

11 See the discussion of the sceptical reception of Orobio's work in Paganini, "Orobio e i suoi lettori," VI-VII, XII-XV.

12 See Kaplan, From Christianity to Judaism, 463: "All passages which might have offended the minds of the Anglican community were rigourously excised." For a study of Aguilar's translation, see David Ruderman's article in the present volume.

13 Myriam Silvera explicitly deals with the question of the intended reader, basically repeating the common idea that the text's purpose coincided with the overall purpose of Sephardic polemical literature, namely "recuperare all'ebraismo i conversos 'dudosos," although not addressed at a popular public, but rather those who had a high level of instruction. See Silvera, "I destinatari delle Prevenciones," in Orobio, Prevenciones divinas, XXV-XXX, here XXX. 
be used when discussing with opponents, notably learned Christians. ${ }^{14}$ I will argue that the style of this Explanation is, accordingly, different from that of the Divine Warnings.

Even if Orobio addressed only a converso reader in both the Explanation and the Divine Warnings, his use of different styles suggests he varied his approach and distinguished between different kinds of readers. The question then becomes relevant how readership reflects on a textual level; hence my plea for a literary, rhetorical or discursive analysis of the Divine Warnings or, for that matter, for all of the Jewish apologetics presented in Spanish and Portuguese. These texts, in whatever literary genre they adopt, prose, poetry or drama, have a hitherto unexploited variety and interplay of implied or staged characters: Jewish, New and Old Christians, Calvinists, Catholics and Muslims. On the discursive level, the persona of the author often explicitly directs himself to an individual or collective addressee ("you" or "we") against a third group ("they") that is, implicitly, also being addressed. ${ }^{15}$ The conversos, or New Christians, had a particular history of displacements, motivated by persecution but also by the demands of their trade activities, which led them to live inand outside of Christianity and Judaism. In their polemical writings, any textual interplay with narrative layers, characters and addressees becomes charged with connotations and possibilities. For example, in two of Antonio Enríquez Gómez's works, Romance al divín mártir Judá Creyente and Inquisicón de Lúcifer y visita de todos los diablos, the champions of Judaism or the victims of the Inquisition are not New Christians, that is, they are not of Jewish descent, but they belong to the Old Christians. ${ }^{16}$ Thus, the author stages a persona who in the mind and discourse of the oppressor was free from any "stained" origin. ${ }^{17}$ Was this a strategy the author chose in order to hold up a mirror to an absent reader-the Catholic Church, the Inquisitionand settle scores, albeit through fiction? Or did he chose the proselytised and victimised Old Christian in order to present Judaism as a choice and liberate his fellow

14 Orobio, Explicación del capítulo 53 de Isaías, Amsterdam, Ets Haim, ms. 48 D 16, f. 1r-v: "Estos discursos sobre el capítulo 53 de Ysaías se escriuieron a instancia de algunas personas que hauitan fuera de judaísmo"; "Suponiendo que esto no se escriue para los doctos se disculpa bastantemente su ynsufiziencia"; "Y aunque los versos que se alegan son tan comunes y savidos entre nosotros que ninguno los ignora, con todo, así juntos y ponderados, están más promtos para valerse dellos en la ocurrencia de semejante conversasción con algunos de los contrarios, particularmente hallando aquí lo que responden los doctores cristianos y como se an de contradecir esas respuestas.”

15 The hitherto neglected importance of the discursive / narrative interplay between religious opponents has been studied by Ryan Szpiech, Conversion and Narrative: Reading and Religious Authority in Medieval Polemic. Philadelphia: University of Pennsylvania Press, 2013; and by Wilke, The Marrakesh Dialogues, however, this applies to the form of dialogue, not to the confutation couched in the form of scholastic treatise.

16 See, respectively, Kenneth Brown, De la cárcel inquisitorial a la Sinagoga de Amsterdam: Edición y estudio del "Romance a Lope de Vera," de Antonio Enríquez Gómez, Toledo: Consejería de Cultura de Castilla-La Mancha, 2007, 167, and Antonio Enríquez Gómez, La Inquisición de Lucifer y visita de todos los diablos, edited by M.P.A.M. Kerkhof and C.H. Rose, Amsterdam: Rodopi, 1992, 5.

17 Or in the Spanish, significant, terminology: "limpio," "no manchado." 
converso readers from the ever-present burden of descent and blood? ${ }^{18}$ I will not go so far as to suggest that Orobio's works have similar discursive complexities, but establishing its readership, distinguishing the (a) textually explicit (addressed); the (b) referred-to and absent addressees or (c) factual readers is also highly relevant for a treatise such as the Divine Warnings. In such an important genre as Jewish apologetics among Sephardim, limited to manuscript circulation but widely distributed nevertheless, an analysis solely dedicated to "contents" or "arguments" is not enough: literary form and rhetoric also play a major part. Even when we consider them nonfiction or doctrinal, the question of language, communication and discourse of "Sephardic Polemics" is essential to a proper understanding of the function and the importance of this genre. The following literary approach to the Divine Warnings is, in this sense, no more than a first contribution. I seek to open the way for further indepth studies.

Before analysing the Divine Warnings itself, let us return to Daniel Levi de Barrios and examine how he perceived the author and his work. In one of his prefatory poems, the Andalusian poet characterises Isaac mainly in military terms, triumphant in (verbal) battles with Christianity, Israel's adversary. Barrios also repeatedly praises Orobio's wisdom, knowledge and wit and celebrates the fame enjoyed by Orobio, even stating his own outspoken envy by presenting himself as a Daniel, fighting for the same cause but ignored. Finally, he mentions Orobio's eloquence. In the poet's typical display of wit, Barrios manages to condense Orobio's writings in a few verses:

\author{
¿Quién a tu valiente sciencia \\ dexará de dar tributo \\ quando triumpha de Thomás \\ y seca el arbor de Lulio? \\ ¡Oh, nunca el prado en sus flores \\ áspides tuviera ocultos! \\ Mas, ¿qué digo? Que tu ley \\ da la triacha en sus frutos. \\ Fuiste Hipócrates de Francia \\ con eloquencia de Tulio, \\ adonde fuiste el primero, \\ y el más docto fue el segundo. ${ }^{19}$
}

Who will deny tribute to your brave science when it triumphs over Thomas and dries up Lull's tree? It would have been better if the meadow had never hidden a snake between its flowers, but let me say that your Law offers the triacle [remedy] in its fruits. You were the Hippocrates of France with the eloquence of Tullius-you were the first there, and the most learned remained second to you.

18 Carsten Wilke, "Conversion ou retour? La métamorphose du nouveau chrétien en juif portugais dans l'imaginaire sépharade du XVIIe siècle," In Mémoires juives d'Espagne et du Portugal, edited by Esther Benbassa (Paris: Publisud, 1996): 53-67.

19 Orobio, Prevenciones divinas, 7. 
Here Barrios ingeniously identifies two principal merits in the doctor's works: his theological knowledge, which undoubtedly implies dialectical skills, and his eloquence, which is likened to Cicero's (Tulio). What Barrios implies is that Orobio triumphed over Catholic Theology, evoked by Thomas Aquinas (Thomás), the foremost theologian in the tradition of scholasticism, and that he was successful in his controversy with Alonso de Zepeda, who had translated Lull's Arbor scientiae. ${ }^{20}$ Through the "hidden snakes" in the meadow (prado), he alludes to Orobio's controversy with his former friend Juan de Prado, ${ }^{21}$ considered a deist by the former. Barrios portrays Orobio as the doctor whose writings provided the remedy against the snake's venom, that is, deism or heresy. As a doctor of medicine he was the first in France, but his second quality, his eloquence, made him the most learned, that is: by his polemical texts he earned the highest esteem.

In my opinion Barrios, whose merits as a poet are subject to discussion, succeeded once again in defining a personality of his Sephardic community with few words but great precision. ${ }^{22}$ Whereas the poet's allusions to Orobio's fame and his knowledge in defense of Judaism would have been recognised by both Iberian and nonIberian readers, only those who read his Spanish originals could fully appreciate his eloquence. But what kind of eloquence was Barrios referring to? In my opinion, the mention of “Tulio" was not a general compliment to Orobio's rhetorical virtues but an identification of the style of the Divine Warnings. I argue that Orobio adopts a Ciceronian style in this text, contrary to the plain (and shorter) style he used in his Reply (Respuesta) to Zepeda, full of puns and wit; or his Explanation of the Fifty-Third Chapter of Isaiah, also written in a plain, shorter style. In the Divine Warnings, Orobio wrote in a prose characterised by a rich variety of devices of amplificatio in what I consider to have been a conscious effort to lend his text a prestige that he did not find necessary to seek for the remainder of his works. In other words, Orobio both in content and style, marked his Divine Warnings as the magnum opus that it was subsequently identified to be by his readers.

Ciceronian style was defended as a stylistic ideal in the Renaissance, before it came under the attack by Justus Lipsius and other adherents of the Attic style in the second half of the sixteenth century; it was still popular among certain authors in the seventeenth century literature of Spain, particularly in devotional texts. What Barrios implied by his claim about the Divine Warnings' Ciceronian style is a matter that certainly merits a more careful analysis than what is presented here. Let it suffice to say that the style of the Divine Warnings, a treatise, does not appear to follow the common dividing lines of the three genera dicendi. According to Latin rhetoric, plain style was used for instruction, middle style for evoking delight and high

20 Kaplan, From Christianity to Judaism, 179-189.

21 Kaplan, From Christianity to Judaism, 329-347.

22 See Wilhelmina C. Pieterse, Daniel Levi de Barrios als geschiedschrijver van de Portugees-Israelietische Gemeente te Amsterdam in zijn 'Triumpho del govierno popular' (Amsterdam: Scheltema \& Holkema, 1968). 
style for stirring emotions. But, thanks to the work of López Grigera, among others, we know that style experienced a notable expansion in the Early Modern Period. Under the influence of Byzantine rhetoric that utilised Greek models as many as seven styles could be chosen, varying from Clarity (sapheneina) to Gravitas (deinotes), and elements of each individual style could be combined. ${ }^{23}$ Orobio's Divine Warnings clearly belong to doctrinal, argumentative prose, which would have required "low" or "plain" style. However, the author clearly wished to adorn, vary and emphasise his discourse adopting "middle style." At this stage of my research, I have not identified a concrete model Orobio considered as stylistic ideal. ${ }^{24}$ To my mind, Orobio's Divine Warnings do not echo any of the great Spanish writers of Golden Age prose such as Francisco de Quevedo or Baltasar Gracián (both famous for their laconic, short style, combined with extremely ingenious or witty discourse); nor Fray Luis de Granada, frequently cited as an example of Ciceronian style. The continuous presence of Latinised words in Orobio's prose, his experience at the University of Alcalá de Henares and the fact that he also wrote in Latin, perhaps points to the influence of contemporary Spanish authors writing in Latin such as Alfonso García Matamoros (d. 1572), who was a professor of rhetoric at the University of Alcalá de Henares and reputed as a Ciceronian.

If identifying a precise stylistic model is difficult, it is far easier to sum up the main elements of Orobio's prose in the Divine Warnings, one of which must strike every reader who makes the effort of digesting the text in its original language: the length of its periods. The very first phrase of the work's prologue occupies no fewer than fourteen lines in Silvera's edition and counts an impressive total of 208 words! Such a phrase is, of course, a challenge to the reader, not only due to its word count but also due to its many subordinate clauses. Lengthy sentences and an understanding of periods different from those that are common nowadays are also present in other works belonging to seventeenth-century Iberian prose, but when the Divine Warnings are compared to other texts by Orobio, it becomes clear that the author made a conscious effort to amplify his prose in pursuit of both a dialectic ideal-that is, fullness of argument-and aesthetics.

23 Luisa López Grigera, La retórica en la España del Siglo de Oro: teoría y práctica. Salamanca: Ediciones Universidad de Salamanca, 1994, 173.

24 Examples of Ciceronian style can be found in Iberian devotional literature, with Fray Luis de Granada as an outstanding example. See Rebecca Switzer, The Ciceronian Style in Fr. Luis de Granada, New York: Instituto de las Españas en los Estados Unidos, 1927; Manuel López Muñoz, Fray Luis de Granada y la Retórica, Almería: Universidad de Almería, 2000. Amplificatio is also found in the works of Abraham Pereyra, La certeza del camino (1666) and Espejo de la vanidad del mundo (1672), largely as a result of the author's plagiarism of Iberian devotional literature, see Henry Méchoulan, Hispanidad y judaísmo en tiempos de Espinoza: Estudio y edición anotada de La certeza del camino de Abraham Pereyra, Salamanca: Universidad, 1987. However, these authors maintain a didactical style, whereas Orobio's periods are larger and more complex-think of the recurring double negations. Also, Orobio's text does not engage with the reader on an emotional level typical of devotional literature but rather on an intellectual one. 


\section{Let us have a closer look at the mentioned first sentence:}

Parecerá justamente improprio al ánimo más cándido y desapacionado que quien no es versado en las Sagradas Letras, mas es totalmente ignorante de sus divinas exposiciones presuma hazer comentos y declaraciones al Sacro Texto, en quien por la maior parte perdió pie el humano juizio, anegado en aquel piélago profundo de lo misterioso que contiene, particularmente después que en nuestra dilatada captividad fuimos privados de aquellos insignes interpretes que de grado en grado, con el tiempo y continuada sucesión de nuestros deméritos, fueron perdiendo aquellas vislumbres que aún quedavan de la divinidad que asistió a nuestros Maiores, hasta degenerar nuestro conocimiento y sabiduría en aquella sola luz que la naturaleza concedió a la racionalidad; quán débil sea esta para ascender a penetrar los divinos secretos que misteriosa oculta la prophesía, lo conoce y confiesa nuestra ignorancia, y la diversidad de pareceres que sobre cada verso escriven nuestros expositores, de que tubo su origen afirmarse que admite muchas faces o sentidos la sacra página, porque expuesta a los ojos de nuestro entendimiento, los raios y luces de su divinidad le ofuscan, y él como corto y débil entiende con tal impropiedad que en ninguna intelligencia se afirma, y solicita varios conocimientos, por si acaso puede encontrar con el verdadero. ${ }^{25}$

For good reason it may seem inappropriate to a naive and unimpassioned mind that someone who not only is no expert in the Holy Scriptures, but who is even entirely ignorant of its divine interpretations, would be pretentious enough to formulate comments and explanations on the Holy Writ, a matter in which human judgment has in most cases lost its foothold, being drowned in the profound ocean of the mysterious message contained therein, especially since we [Jews] in our protracted captivity were deprived of those distinguished interpreters who gradually with time and the continuous succession of our unworthy acts have lost those faint glimmers lingering on from the Godhead that once supported our ancestors, until our knowledge and wisdom degenerated to the bare light that nature has conceded to our rational being; and what a weak tool this is in helping us climb towards the deep secrets that prophecy has mysteriously enshrouded, is well recognised and confessed by the ignorance and diversity of opinions that our commentators show in their writings on each and every scriptural verse, from where originated the statement that the Holy Pages allow many aspects or meanings, because, when the eyes of our understanding are exposed to them, the beams and lights of the Godhead blind it, and short-sighted and weak-minded as it is, it understands them in such an inadequate manner that it does not manifest intelligence whatsoever and evokes various types of knowledge in the hope of possibly hitting the true one.

Analysing these sentences on a syntactic and lexical level, a characteristic feature of the Divine Warnings' prose comes to light. Orobio makes a consistent effort to amplify words and notions through synonyms in groups of two, which is evident in the above passage: "naive and unimpassioned," "comments and explanations," "knowledge and wisdom," "recognised and confessed," "ignorance and diversity of opinions," "aspects or meanings," "beams and lights," "short-sighted and weak-minded.” Orobio occasionally clusters three synonyms: "gradually with time and the continuous succession.” Not only is this opening phrase of the Divine Warnings extraordinarily laden with such couplings and combinations, this practice is strikingly common

25 Orobio, Prevenciones divinas, 12. 
throughout the entire text, at least of the first part of the Divine Warnings. ${ }^{26}$ Such a practice of amplificatio is present only to a much lesser degree in Orobio's other writings, such as his Reply to Zepeda or the Explanation of the Fifty-Third Chapter of Isaiah. The French translator of the 1770 edition of his text had no trouble at all in leaving such duplications out, considerably shortening his translation.

A very similar principle governs a profuse construction of parallel clauses, also appearing in double or triple combinations. Thus in his first chapter, titled "Proof that God has warned Israel in the Five Books of the Law against all the idolatries of the Gentiles, against the philosophers, and against the Trinity that the Christians would invent" (Prueva que en los Cinco Livros de la Ley previno Dios a Israel contra todas las idolatrías de las Gentes, contra los philósophos y contra la trinidad que avían de inventar los Christianos) observe the triple occurrence of the syntagm initiated by contra) the author begins with a series of negations, balanced by another series of affirmations (both marked in cursive):

Lo primero se responde al propuesto argumento que de ninguna manera era necessario que Dios nuestro Señor expresase en el divino oráculo la christiana secta, nombrándola con el mismo nombre que le avian de imponer los hombres, ni llegar a individuar sus falsas doctrinas, ritos y fingidos misterios, como tampoco lo hizo en las fabulosas deidades de la antigua Gentilidad, ni habló de Saturno, Júpiter, Marte, Baco, Venus, y los demás, ni hizo mención de las supersticiones de su falso culto, aviendo sido no menos célebre esta idolatría, ni menos universal, y no poco nociva a Israel; mas assi esta passada, como la presente, las previno el Señor Dios a su amado pueblo en la Ley divina que es archivo y summa de toda la prophesía: ally vocalmente fueron enseñados de quanto bastó para no admitir y arros[=j]ar de sí quantas idolatrías y supersticiones podía inventar la malicia o la ignorancia de los hombres en todos los tiempos. ${ }^{27}$

To the alleged argument, one can first of all reply that is was in no way necessary that God our Lord would identify the Christian sect in the divine oracle by designing it with the same name that humans would attribute to it; and it was no more necessary that He would go into explicating its false doctrines, rites and invented mysteries, as He did not do this for the fabulous divinities of pagan antiquity, since he has indeed not spoken of Saturnus, Jupiter, Mars, Bacchus, Venus and the others, nor has he left any mention of the superstitious customs of their false worship, although that idolatry was no less famous, no less universal, and no less harmful to Israel, but it happened to that of the past just the same as to the one existing at present: the Lord God has announced them to his much-beloved people in the Divine Law, archive and sum of all prophecy, where He has outspokenly taught as much as was necessary in order to discard and reject whatever idolatries and superstitions human wickedness or ignorance of all times would be able to invent.

Within these opposed units, both containing extensive enumerations-another principle of amplificatio-one finds a series of double negations like "no less famous,"

26 I refer to the first part of the Divine Warnings, the main subject of my analysis. The second part, hitherto not available in a modern edition contains significant variations, as I have observed in the chapters devoted to the Jewish reading of Isaiah 53, which Orobio had issued as a separate text. 27 Orobio, Prevenciones divinas, 20-21. 
"no less universal" and "no less harmful." A text laden with the density of these devices demands a concentrated, educated, trained reader.

On the lexical level, Orobio introduced another challenge by consistently using a terminology derived from Latin and rare in common, spoken Spanish. Such a use of uncommon words, called cultismos in Spanish, was a characteristic feature of baroque culterano prose of writers as Luis de Góngora, who cultivated a deliberately obscure style by transposing Greek and Latin words in Spanish and creating neologisms in combination with contrived mythological allusions and by using a syntax that stretched and forced the limits of Spanish language. Orobio's use of cultismos, by contrast, does not pursue such a sophisticated game of hide and seek with the reader; rather, it reflected the author's deliberate intent to create a prestigious, exact, scholarly discourse. In such words as

abominable, alegaciones, calificar, canonizar, chancelar, ${ }^{28}$ conturbar, corroborar, dilatación, distinto, disuadir, engendrador, étnico, execrable, figurado, honestar, humanado, idiota, implicarse, implicatorio, improporcioniado, individuar, infando, infausto, intimar, irrefragable, materialidad, nefando, nocivo, occurrir, ofuscar, opífice, participar, prevaricación, prevención, proposición, publicano, repugnar, seductor, semejado, simulacro, subvertido, sumergir, supuesto, violentando, and vocalmente,

one finds terms that are either highly uncommon in contemporary seventeenth-century Castilian prose (étnico, ${ }^{29}$ implicatorio, ${ }^{30}$ infando, ${ }^{31}$ irrefragable ${ }^{32}$ ); hard to recognise in the specific use conferred on them by Orobio (ocurrir, implicarse); or representative of a very technical, scholastic or theological repertory (abominable, irrefragable, chancelar).

With the three levels of difficulty just mentioned: (a) extreme length and amplification, (b) continuous duplications, multiplications and opposing sets, and (c) preference for an abstruse and/or highly technical lexicon, the modern reader of Orobio's Divine Warnings wonders what contemporary reader the author precisely had in mind. One cannot uphold the all too general assumption that Orobio's text, as all vernacular apologetics produced by the Sephardim, was meant for a former converso

28 Chancelar or cancelar is not only used in the meaning of "to annul," but also with the precise meaning of to remove authority (from a text or argument). Cf. Diccionario de Autoridades (17261739), s.v. 'cancelar': "y quitar la autoridad a algún instrumento público, lo que se hace cortándole, o cortando el signo, para denotar que queda inútil y sin alguna autoridad o fuerza.”

29 Ét(h)nico: "lo mismo que gentil" (Diccionario de Autoridades, s.v. "éthnico"). The word is thus used as synonym for "gentile," "non-Jewish," belonging to the peoples.

30 Implicar is frequently used by Orobio in the sense "oponerse o contradecirse un término u proposición con otra, destruyéndose"; that is to counter an argument with another (see Diccionario de Autoridades, s.v. "Implicar," as the secondary meaning. "Implicatorio" would then mean "contradictory" or "contrary."

31 Infando: "Infame, ilítico y que no es digno de que se hable de ello" (Diccionario de Autoridades, s.v.).

32 Irrefragable: "lo que no se puede impugnar ni contradecir" (s.v. Diccionario de Autoridades). 
reader who needed reassurance in his return to Judaism or who required an arsenal of arguments to counter his Christian adversary. The Divine Warnings can hardly be considered a manual. This does not mean, however, that Orobio targeted this work towards non-Jewish readers, although it sets it apart from other ones, like the Explanation, where he specifically addressed a non-instructed converso. ${ }^{33}$ The Explanation also features lengthy phrases or periods but generally lacks repetitions, parallel constructions or double negations; more importantly, its vocabulary hardly has any technical philosophical or theological terms. As is known, the second part of the Divine Warnings includes a large part of the Explanation of the Fifty-Third Chapter of Isaiah, taken verbatim and without modification. ${ }^{34}$ The difference in style with regards to the first part of the Divine Warnings is evident. This is perhaps due to the different genre of text used in the Explanation: it is a Jewish exegesis of Isaiah and other prophetical writings. Contrary to the first part of the Divine Warnings, the Explanation also contains an occasional element of scorn, which had not been present before. ${ }^{35}$ In this text, Orobio also referred to the implied reader he had already addressed in the prologue.

In contrast, the author of the first part of the Divine Warnings made an effort to elevate his work both intellectually and stylistically, without, however, pursuing an ideal of obscuritas. In several areas, Orobio was very clear. As has been observed, no one before him was so explicit in his rejection of Christianity as the Orobio of the Divine Warnings. If the continuous use of amplificatio can be considered an aesthetic ideal, it also serves the purpose of creating the hammering effect of emphasis. Through repetitions and variations, Orobio leaves his adversary no breath to formulate counter-arguments, and even a reader who does not grasp every detail present in the author's lengthy phrases-and arguments-inevitably becomes pervaded by the insistent, repetitive structure of the Divine Warnings's prose. The rhetorical quality of emphasis is present on many other levels throughout the text. Again, word choice plays an important part. If Orobio's prose is considered so fierce, this is largely to be attributed to a very consistent use of derogatory qualifiers. From its title on, the author used a very forceful term in favor of Judaism, qualifying Christians as "idolaters.” Even if this term might have lost power through its almost ritualistic use in the Sephardic congregations (think of the condemnation of travels to the "lands of idolatry" at the synagogue), it was reinforced by a whole sphere of adjectives and

33 See supra, 9-10, 67, 80-81.

34 Although this point requires further analysis, the stylistic differences between the first part of the Divine Warnings and the commentary on Isaiah present in chapters 25-26 of the second part would suggest that Orobio made use of his previous writings. In this case, the Explanation of the Fifty-Third Chapter of Isaiah must have been written before the second part of his Divine Warnings.

35 See, for example, Orobio's ridiculizing the moaning and tearful Paul; Orobio, Explicación, Ets Haim Ms. 48 D 16, 70: "nunca se dixo en las sagradas letras, ni se advertió en la ley, ni lo lloraron los prophetas, ni hizieron mención de tal reprovación y destierro de Dios, como después lo gimió y lloró Paulo en todos sus escritos." 
nouns meant to defy and beat the adversary. Christians and their beliefs were depicted as "vain" (vana idolatría, vano culto, but also vanas opiniones and vanas e impossibles representaciones), their beliefs depicted as illusory, unreal and lying, which is reflected in such nouns as mentidas sombras, verbs as pretenden and intentar, and adjectives as fingido, falso, chimérico. Christians are tainted with either irrational stupidity (idiota, desatino, absurdo, yerro) or treacherous manipulation (pervertido, sofístico, ingenioso, etc).

Scholars who have drawn attention to Orobio's presentation of Judaism as characterised by its rationalism ${ }^{36}$-without ignoring the fundamental role of prophecyhave also identified the author's continuous use of the powerful metaphor of light and darkness, which, common as it may be in religious and scientific polemics of the Early Modern Age, is still handled with skill and subtlety. Two more "semantic fields" used in depicting Christians have been singled out and come to the fore when Orobio's Divine Warnings is textually analysed. One is the adoption of derogatory qualifiers that contaminate Christians with impurity (immundos) or low moral standards (facinerosos, infames, audaces, audacia, desordenado apetito, desordenada codicia). ${ }^{37}$ If Orobio's use of "impurity" already echoes a discursive practice in Sephardic literature turning upside down a hegemonic and omnipresent Iberian discourse levelled at the New Christian tainted by his blood, Kaplan and others have also recognised another core element of Orobio's anti-Christian rhetoric, deeply motivated by the traumatic experience of a declassed and despised minority of conversos or New Christians: the depiction of Christianity as a doctrine of common people, those of unnoble birth. In the Divine Warnings, Christians are identified as "rabble," "plebeian," and "barbarian" (vulgo, plebe and bárbaro), having their origin in "villains, fishermen, publicans, and public harlots" (vulgares, pescadores, publicanos y públicas rameras). Here again former conversos inverted the social rejection they were confronted with, bringing the argument back to the adversary.

Demystified and debunked as the false Messiah of a false religion, Orobio voids Christ of any possible prestige by consistently referring to him as "that man" (aquel hombre) or "a dead man" (un hombre muerto). In the context of the Divine Warnings these invectives do perhaps not add much force to a discourse that is sharp enough to stand on its own. The author does not look for the scandal in vituperating the Christian Messiah, contrary to other Jewish polemical texts. The element of humour and mockery, which Orobio had used in other texts, notably against Zepeda, is absent from the Divine Warnings. Given the exegetical purpose of the text announced

36 Kaplan, From Christianity to Judaism, 377: "behind his fierce longing for Israel's liberation from subservience to the Gentiles, one can detect the warning accents of a sober and conservative rationalism."

37 Orobio, however, does not go so far as to attribute animal characteristics to Christians: the word brutos appears in his text but is not explicitly related to Christianity. In this sense, the author rejects a derogatory discourse, such as found in the fiercest Iberian anti-Jewish literature. 
in its title, an analysis of "divine warnings" to be found in the Scriptures, such a device was perhaps not to be expected.

Based upon a literary reading of the Divine Warnings after a first analysis of its style and its rhetoric, what was to be expected from Orobio's magnum opus? I venture that much of its intention derives from the author's highly original conception of an alternative teleological reading of the Bible. Orobio and his fellow New Christians had been continuously confronted with a tradition of Christological interpretation of the so-called Old Testament, in which it was argued that the coming of Christ represented the true fulfilment of biblical prophecies, invariably accompanied by the exposition and derision of blind, stubborn Jews. In his magnum opus, Orobio introduced an alternative, subversive Christological reading of the same Scriptures, divinely revealing the falseness and blindness of Christianity. Orobio's elaborate prose created a monument in words, not primarily meant to instruct the former converso, but to strengthen his new identity by the means of counter-discourse.

\section{Works Cited}

Amsterdam, Ets Haim, ms. 48 D 16.

Benítez, Miguel. La face cachée des Lumières: Recherches sur les manuscrits philosophiques clandestins de l'âge classique. Paris: Universitas, 1996.

Boer, Harm den. La literatura sefardí de Amsterdam. Alcalá de Henares: Universidad, 1996.

Brown, Kenneth, and Harm den Boer, El Barroco sefardí: La poesía de Abraham Gómez Silveira, estudio y edición. Kassel: Reichenberger, 2000.

Brown, Kenneth. De la cárcel inquisitorial a la Sinagoga de Amsterdam: Edición y estudio del "Romance a Lope de Vera," de Antonio Enríquez Gómez. Toledo: Consejería de Cultura de Castilla-La Mancha, 2007.

Diccionario de Autoridades. Edited by Real Academia Española (1726-1739); online edition http:// web.frl.es/DA.html.

Enríquez Gómez, Antonio. La Inquisición de Lucifer y visita de todos los diablos. Edited by Maxim P.A.M. Kerkhof and Constance H. Rose. Amsterdam: Rodopi, 1992.

Kaplan, Yosef. From Christianity to Judaism: The Story of Isaac Orobio de Castro. Oxford: Oxford University Press, 1989.

López Grigera, Luisa. La retórica en la España del Siglo de Oro: teoría y práctica. Salamanca: Ediciones Universidad de Salamanca, 1994.

López Muñoz, Manuel. Fray Luis de Granada y la Retórica. Almería: Universidad de Almería, 2000. Méchoulan, Henry. Hispanidad y judaísmo en tiempos de Espinoza: Estudio y edición anotada de La certeza del camino de Abraham Pereyra. Salamanca: Universidad, 1987.

Orobio de Castro, Isaac. Prevenciones divinas contra la vana idolatría de las gentes, vol. 1. Edited by Myriam Silvera. Florence: Leo S. Olschki, 2013.

Paganini, Gianni. “Orobio e i suoi lettori dall'ebraismo all'illuminismo." In Orobio, Prevenciones divinas, $\mathrm{V}-\mathrm{XV}$.

Pieterse, Wilhelmina C. Daniel Levi de Barrios als geschiedschrijver van de Portugees-Israelietische Gemeente te Amsterdam in zijn "Triumpho del govierno popular." Amsterdam: Scheltema \& Holkema, 1968.

Popkin, Richard H. "The Role of Jewish Anti-Christian Arguments in the Rise of Skepticism." In New Perspectives on Renaissance Thought: Essays in the History of Science, Education and 
Philosophy in Memory of Charles B. Schmidt, edited by J.H. Hutton and S. Hutton, 159-180. London: Duckworth, 1990.

Sutcliffe, Adam. "Judaism in the Anti-Religious Thought of the Clandestine French Early Enlightenment." Journal of the History of Ideas 64, no. 1 (2003): 97-117.

Sutcliffe, Adam. Judaism and Enlightenment. Cambridge: Cambridge University Press, 2003.

Switzer, Rebecca. The Ciceronian Style in Fr. Luis de Granada. New York: Instituto de las Españas en los Estados Unidos, 1927.

Szpiech, Ryan. Conversion and Narrative: Reading and Religious Authority in Medieval Polemic. Philadelphia: University of Pennsylvania Press, 2013.

Wilke, Carsten L. "Conversion ou retour? La métamorphose du nouveau chrétien en juif portugais dans l'imaginaire sépharade du XVIle siècle." In Mémoires juives d'Espagne et du Portugal, edited by Esther Benbassa, 53-67. Paris: Publisud, 1996.

Wilke, Carsten L. The Marrakesh Dialogues: A Gospel Critique and Jewish Apology from the Spanish Renaissance. Leiden: Brill, 2014.

Yerushalmi, Yosef Hayim. From Spanish Court to Italian Ghetto: Isaac Cardoso: A Study in Seventeenth-Century Marranism and Jewish Apologetics. New York: Columbia University Press, 1971. 
Brought to you by | Universitaetsbibliothek Basel

Authenticated Download Date | 11/5/18 12:19 PM 